\title{
Two Phases of Rod Photoreceptor Differentiation during Rat Retinal Development
}

\author{
Eric M. Morrow, Michael J. Belliveau, and Constance L. Cepko \\ Department of Genetics and Howard Hughes Medical Institute, Harvard Medical School, Boston, Massachusetts 02115
}

\begin{abstract}
We have conducted a comprehensive analysis of the relative timing of the terminal mitosis and the onset of rhodopsin expression in rod precursors in the rat retina in vivo. This analysis demonstrated that there are two distinct phases of rod development during retinal histogenesis. For the majority of rod precursors, those born on or after embryonic day 19 (E19), the onset of rhodopsin expression was strongly correlated temporally with cell cycle withdrawal. For these precursors, the lag between the terminal mitosis and rhodopsin expression was measured to be 5.5-6.5 d on average. By contrast, for rod precursors born before E19, the lag was measured to be significantly longer, averaging from 8.5 to $12.5 \mathrm{~d}$. In addition, these early-born rod precursors seemed to initiate rhodopsin expression in a manner that was not correlated temporally with the terminal mitosis. In these cells, onset of rhodopsin expression
\end{abstract}

Rods are highly specialized, light-sensing neurons with elaborate outer segments containing the photopigment rhodopsin. Although the morphology and molecular physiology of rod photoreceptors have been well studied, the steps that lead from a multipotent retinal progenitor to a committed rod precursor and finally to a terminally differentiated rod remain poorly understood.

Retinal cell-type specification is likely to involve an interaction between extrinsic and intrinsic regulators (for review, see Reh, 1991; Cepko et al., 1996). Extrinsic cues implicated in rod development in vitro include taurine (Altshuler et al., 1993), S-laminin (Hunter et al., 1992), retinoic acid (Kelley et al., 1994), and the CNTF family of cytokines (Fuhrmann et al., 1995; Kirsch et al., 1996; Ezzeddine et al., 1997; Neophytou et al., 1997). These studies have all used rhodopsin expression as an assay for rod differentiation. To date, two transcription factors have been molecularly characterized that bind to and transactivate from promoters of photoreceptor-specific genes in vitro, namely NRL (Kumar et al., 1996; Rehemtulla et al., 1996) and Crx (Chen et al., 1997; Furukawa et al., 1997). The roles that the above-mentioned cell autonomous and cell nonautonomous activities play in rod commitment, and the potential timing of action of these factors

Received Dec. 12, 1997; revised March 4, 1998; accepted March 5, 1998.

This work was supported by National Institutes of Health Grants EY09676 and EY08064. We thank Dr. R. S. Molday for an ample supply of the Rho4D2 antibody, and M. Zeidler for help with confocal microscopy. E.M.M. also thanks in particular Diala Ezzeddine for helpful discussions during the course of the work and for a thorough and critical reading of this manuscript. As well, we thank Z.-Z. Bao, A. Chen, and D. Schulte for feedback on this manuscript, and members of the Cepko/ Tabin Lab for help while these experiments were conducted.

Correspondence should be addressed to Constance L. Cepko, Department of Genetics and Howard Hughes Medical Institute, Harvard Medical School, 200 Longwood Avenue, Boston, MA 02115.

Copyright (C) 1998 Society for Neuroscience $\quad 0270-6474 / 98 / 183738-11 \$ 05.00 / 0$ appeared approximately synchronous with later-born cells, suggesting a synchronous recruitment to the rod cell fate induced by environmental signals. To examine this possibility, experiments in which the early-born precursors were exposed to a late environment were conducted, using a reaggregate culture system. In these experiments, the early-born precursors appeared remarkably uninfluenced by the late environment with respect to both rod determination and the kinetics of rhodopsin expression. These results support the idea that intrinsically distinct populations of rod precursors constitute the two phases of rod development and that the behavior exhibited by the early-born precursors is intrinsically programmed.

Key words: rodent retina; rod photoreceptors; rhodopsin; cell fate determination; differentiation; neurodevelopment

in the life history of a developing rod in vivo, are areas of active study.

Lineage analysis supports the idea that commitment to the rod cell fate may occur during or after the terminal mitosis because two cell clones with one rod and a second distinct cell type were found (Turner and Cepko, 1987). As well, other studies have directly demonstrated persistent developmental plasticity in some postmitotic retinal cells in vitro (Belecky-Adams et al., 1996; Ezzeddine et al., 1997). In one of these studies, in which developing retinal explants were treated with ciliary neurotrophic factor, postmitotic rod precursors were respecified to express at least three markers of bipolar interneurons, and rhodopsin expression was blocked, suggesting a switch in cell fate. Furthermore, the window of sensitivity to the effects of factor treatment in rod precursors was found to extend to shortly before the expression of rhodopsin (Ezzeddine et al., 1997).

Several studies across different species have reported a long delay between the terminal mitosis of a rod precursor and the onset of rhodopsin expression (for review, see Cepko, 1996). In the present study, we set out to answer the following question in the developing rat retina: is there a correlation between the day a rod precursor is born and the day it expresses rhodopsin? Our results demonstrate that there is a strong temporal correlation between the day of birth of a rod precursor and the onset of rhodopsin expression among cells born on or after embryonic day 19 (E19). Interestingly, a different behavior is exhibited by rod precursors born before E19, indicating that there are two phases of rod development: an early phase and a late phase. We tested whether extrinsic cues from the late phase could alter the differentiation of rods born during the early phase. The results are consistent with the notion that intrinsically distinct populations of 
rod precursors participate in the two different phases of rod development.

\section{MATERIALS AND METHODS}

Animals. Timed-pregnant Sprague Dawley rats were purchased from Taconic (Germantown, NY). Most of the litters were born on E22, which was considered equivalent to postnatal day 0 (P0).

In vivo $\left[{ }^{3} \mathrm{H}\right]$ thymidine pulse-labeling. $\left[{ }^{3} \mathrm{H}\right]$ thymidine (Amersham, Arlington Heights, IL) $(5 \mu \mathrm{Ci} / \mathrm{gm}$ of animal) was administered by a single intraperitoneal injection to pregnant rats (embryonic time points) or separately to neonatal littermates (postnatal time points).

In vitro $\left[{ }^{3} H\right]$ thymidine pulse-labeling and BrdU labeling of retinal explants. Pulse-labeling in vitro was performed by placing P0 explanted retinae in DMEM (Life Technologies, Gaithersburg, MD) containing $10 \%$ fetal calf serum (FCS) (Life Technologies) to which a final concentration of $5 \mu \mathrm{Ci} / \mathrm{ml}\left[{ }^{3} \mathrm{H}\right]$ thymidine was added. After a $1 \mathrm{hr}$ incubation at $37^{\circ} \mathrm{C}$, retinae were washed five times and cultured as explants as described previously (Lillien and Cepko, 1992) in DMEM containing $10 \%$ FCS and penicillin-streptomycin (100 U/ml) (Life Technologies). Cells undergoing S-phase in culture were labeled by BrdU addition after different time intervals to a final concentration of $10 \mathrm{~mm}$.

Retinal dissociations. A developmental series (P0-P20) of retinae from $\left[{ }^{3} \mathrm{H}\right]$ thymidine-labeled littermates or tissue from cultured explants was analyzed by gentle dissociation. Dissociations were conducted as described by Altshuler and Cepko (1992) with slight modification. Briefly, neural retinae were dissected free of other ocular tissues and incubated for $10 \mathrm{~min}$ at room temperature in HBSS lacking $\mathrm{Ca}^{2+} / \mathrm{Mg}^{2+}$ (Life Technologies) to which trypsin (Worthington, Freehold, NJ) was added to a final concentration of $1 \mathrm{mg} / \mathrm{mL}$. After trypsinization, soybean trypsin inhibitor (Sigma, St. Louis, MO) was added to a final concentration of $2 \mathrm{mg} / \mathrm{ml}$. The cells were then pelleted by centrifugation (1200 rpm, $5 \mathrm{~min}$ ), resuspended, and gently triturated to a single cell suspension in HBSS containing $100 \mu \mathrm{g} / \mathrm{ml}$ DNase I (Sigma). Cells were then plated on poly-D-lysine (Sigma)-coated, eight-well glass slides (Cel-Line Associates, Newfield, NJ) before fixation.

Immunocytochemistry and autoradiography. Slides with $\left[{ }^{3} \mathrm{H}\right]$ thymidinelabeled cells were first immunostained and then processed for autoradiography. After they were plated, retinal cells were fixed with $4 \%$ paraformaldehyde for $5 \mathrm{~min}$ before they were blocked for $30 \mathrm{~min}$ in PBS, $2 \%$ donkey serum (Jackson ImmunoResearch, West Grove, PA), and $0.1 \%$ Triton X-100 (Sigma). The Rho4D2 monoclonal antibody raised against bovine rhodopsin was a generous gift of Dr. R. S. Molday (University of British Columbia) and was used at a 1:250 dilution (Molday, 1989). BrdU detection was performed using the anti-BrdU monoclonal antibody containing nuclease (Amersham) as instructed by the supplier, with the following modification. Cells were treated with $2 \mathrm{~N}$ $\mathrm{HCl}$ for $20 \mathrm{~min}$ after fixation, followed by eight washes with HBSS, $\mathrm{pH}$ 7.4, before they were blocked. A Texas Red-conjugated, donkey antimouse IgG secondary antibody (Jackson ImmunoResearch) was used according to the supplier's instructions for indirect immunodetection. Nuclear staining was performed by adding 4',6-diamidine-2phenylindole-dihydrochloride (DAPI) to the secondary antibody solution to a final concentration of $0.0005 \%$. After they were immunostained, the slides were dehydrated and stored at $4^{\circ} \mathrm{C}$ before autoradiography.

Dehydrated slides with $\left[{ }^{3} \mathrm{H}\right]$ thymidine-labeled cells were dipped in NTB2 autoradiography emulsion (Kodak, Rochester, NY). Slides were stored at $4^{\circ} \mathrm{C}$ in the dark while they were exposed for 4-10 weeks for in vivo labeling experiments or 1-2 weeks for in vitro labeling experiments. Slides were then developed for $5 \mathrm{~min}$ in D19 developer (Kodak) and rinsed in distilled water followed by $20 \mathrm{~min}$ in fixer (Kodak). Slides were washed with distilled water for $10 \mathrm{~min}$ and then mounted in gelvatol (Rodriquez and Dunhardt, 1960).

Fluorescent microscopy and scoring cells undergoing terminal mitosis. Doubly processed slides were viewed using a Zeiss Axiophot fluorescent microscope. Silver grains were counted under transmission light microscopy using a $63 \times$ Plan NEOFLUAR objective (Zeiss). Cells were determined to have undergone their terminal mitosis on the day of the $\left[{ }^{3} \mathrm{H}\right]$ thymidine pulse if they contained more than half the number of silver grains of the most heavily labeled cell in a given sample.

Reaggregate pellet cultures. The reaggregate pellet culture protocol was modified from Watanabe and Raff (1990) (see schematization in Fig. $6 A)$. Retinae from E16 rats were dissected and labeled with $5 \mu \mathrm{Ci} / \mathrm{ml}$ $\left[{ }^{3} \mathrm{H}\right]$ thymidine for $1 \mathrm{hr}$ before dissociation (as described above). $\left[{ }^{3} \mathrm{H}\right]$ thymidine-labeled E16 retinae were dissociated, and cells were counted and pelleted in a microcentrifuge tube containing 20 - to 50-fold excess unlabeled $\mathrm{P} 0$ retinal cells by centrif ugation for $7 \mathrm{~min}$ at $1150 \times g$. The total number of cells per pellet was $5 \times 10^{5}$ cells. Pellets were transferred to nucleopore polycarbonate membranes, $0.2 \mu \mathrm{m}$ pore size (Costar Nucleopore, Charlotte, NC), and cultured for 3-17 d as described for explants (Lillien and Cepko, 1992) in 45\% DMEM, $45 \%$ Ham's F12 Nutrient Mixture (Life Technologies), 10\% FCS, and penicillin-streptomycin $(100 \mathrm{U} / \mathrm{ml})$. At the end of the culture period pellets were dislodged from the membranes, dissociated, and processed autoradiographically and immunocytochemically as described above. PKH-2 and PHK-26 dye-labeled cells were produced according to the directions of the supplier (Sigma). Cells were labeled in the indicated dye diluted to $4 \mu \mathrm{M}$ in diluent for $5 \mathrm{~min}$. The labeling reaction was halted by adding an equal volume of FCS and then washed several times in culture medium. Reaggregate cultures were produced as described above. Imaging of dye-labeled cells was performed on a Leica TCS-NT confocal microscope.

\section{RESULTS}

\section{Measuring the timing of the terminal S-phase in retinal cells}

A goal of this study was to conduct a comprehensive analysis of the relative timing of cell cycle withdrawal and the onset of rhodopsin expression in developing rods in vivo. To measure the timing of cell cycle withdrawal of retinal cells in vivo, the classic $\left[{ }^{3} \mathrm{H}\right]$ thymidine "birthdating" method was used (Sidman, 1970). This method involves administering a pulse of $\left[{ }^{3} \mathrm{H}\right]$ thymidine in vivo during development. Cells in S-phase at the time of the pulse incorporate $\left[{ }^{3} \mathrm{H}\right]$ thymidine into the DNA of their daughter cells. Daughter cells that continue to proliferate subsequent to the pulse dilute the $\left[{ }^{3} \mathrm{H}\right]$ thymidine in an approximately binary manner with each cell division. Daughters of cells undergoing their terminal S-phase at the time of the pulse remain "heavily labeled" and are termed "born" at the time of or shortly after the pulse. The degree of $\left[{ }^{3} \mathrm{H}\right]$ thymidine labeling can be measured by scoring silver grain numbers after autoradiographic processing of the tissue.

For the present study, two modifications to the classic $\left[{ }^{3} \mathrm{H}\right]$ thymidine birthdating procedure were made. First, to facilitate cell and silver grain counting, heavily labeled cells were scored after dissociation of the retina. This was found to be necessary for accurate quantification because of high cell density in the outer nuclear layer and the small size of rod nuclei. The second modification to the classic birthdating method was that instead of relying on morphology to identify cell type, we used indirect immunocytochemistry against rhodopsin protein using the antirhodopsin antibody Rho4D2 (Molday, 1989). Figure $1 A, B$ shows an example of a heavily labeled cell that is immunoreactive for rhodopsin.

In addition to these modifications, the following control studies were performed to evaluate the criterion for heavily labeled cells. The classic studies (Carter-Dawson and LaVail, 1979) and other more recent studies (Alexiades and Cepko, 1997; Ezzeddine et al., 1997) have used more than half the grain number of the most heavily labeled cell in an experiment as the criterion for heavily labeled. Another recent study has used the criterion of one-fourth or greater (Arimatsu et al., 1994). Figure $2 A$ presents examples of distributions of grain number for retinae injected on E17 and harvested on P1 or P15. To test the cutoff of more than half the most heavily labeled cell, cells were pulse-labeled in vivo at P0 and in vitro in $\mathrm{P} 0$ explant culture. Subsequent to $\left[{ }^{3} \mathrm{H}\right]$ thymidine pulse-labeling, littermates were pulsed with BrdU, or BrdU was added to a retinal explant culture for cumulative labeling, at 5, 12, 24 , or $48 \mathrm{hr}$ after $\left[{ }^{3} \mathrm{H}\right]$ thymidine pulse. At $\mathrm{P} 4$ in vivo or after $4 \mathrm{~d}$ of culture, the percentage of $\left[{ }^{3} \mathrm{H}\right]$ thymidine heavily labeled cells that incorporated BrdU at the different times of BrdU addition 


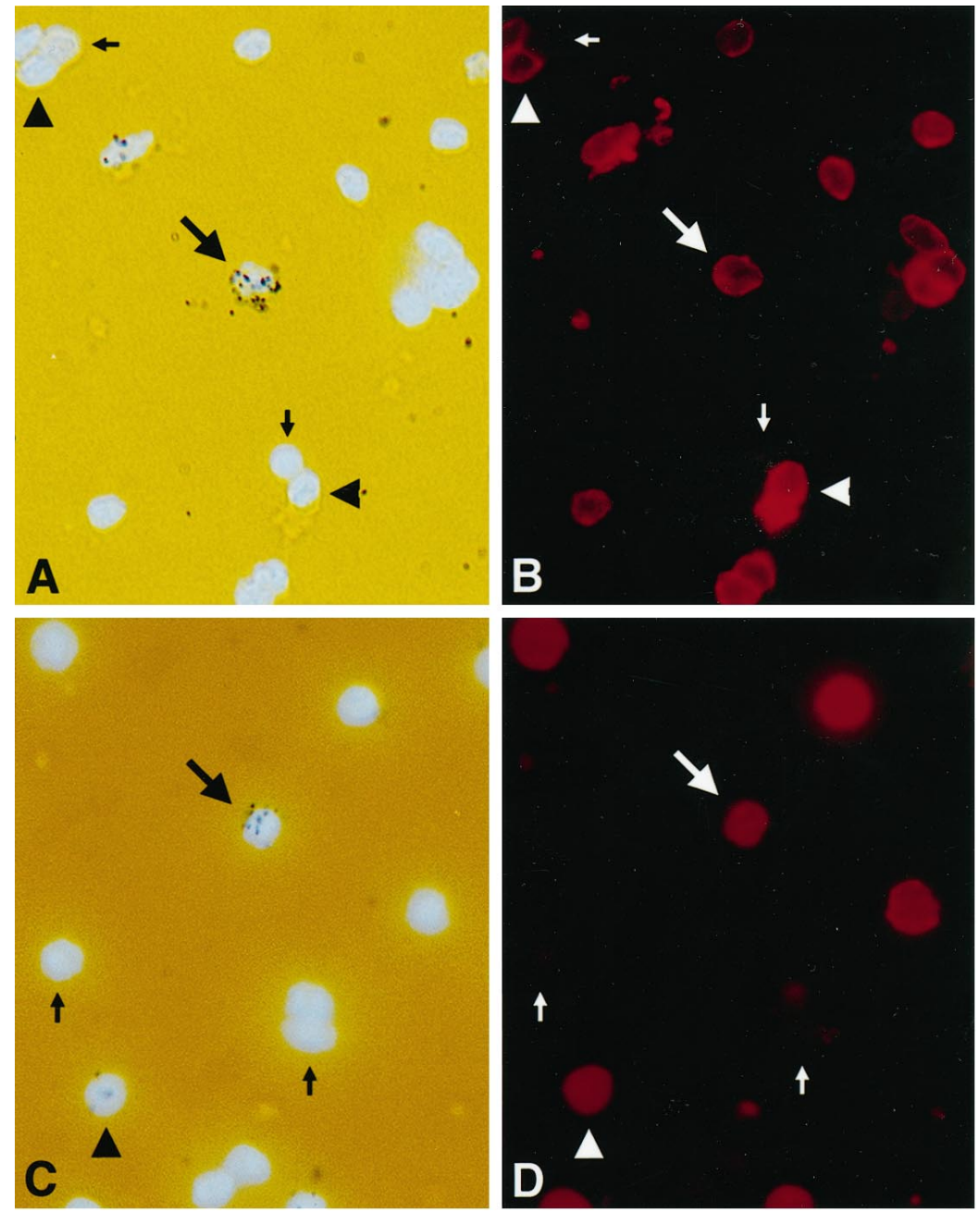

Figure 1. Immunofluorescent and autoradiographic analysis of dissociated retinal cells. $A$, Cell heavily labeled for $\left[{ }^{3} \mathrm{H}\right]$ thymidine that was also immunoreactive with Rho4D2, shown in $B$ (large arrow). $C$, Cell heavily labeled for $\left[{ }^{3} \mathrm{H}\right]$ thymidine that was also immunoreactive for BrdU incorporation, shown in $D$ (large arrow). Arrowheads mark examples of immunoreactive cells that were not heavily labeled by $\left[{ }^{3} \mathrm{H}\right]$ thymidine. Small arrows mark examples of cells that were negative for staining with the corresponding primary antibody. Cells in $A$ and $C$ were viewed under bright-field and UV optics. The nuclei were stained by the nuclear stain DAPI. Cells in $B$ and $D$ were viewed under fluorescent light conditions suitable for detecting the Texas Red-conjugated secondary. Note that Rho4D2 staining was membrane-associated, whereas staining for BrdU incorporation was nuclear. was evaluated. In this way, the length of time after the $\left[{ }^{3} \mathrm{H}\right]$ thymidine pulse when heavily labeled cells (using the criterion of more than half the most heavily labeled cell) stopped incorporating BrdU, and therefore left the cell cycle, could be evaluated. Figure $1 C, D$ shows an example of a $\left[{ }^{3} \mathrm{H}\right]$ thymidine heavily labeled cell that was also positive for BrdU incorporation.

Figure $2 B$ shows the results from the in vitro explant control experiment. These data show that $91.5 \pm 1.0 \%$ of cells were heavily labeled with $\left[{ }^{3} \mathrm{H}\right]$ thymidine and labeled for BrdU incorporation when BrdU was added to the culture $1 \mathrm{hr}$ after the $\left[{ }^{3} \mathrm{H}\right]$ thymidine pulse, or $49.4 \pm 2.2 \%$ when the BrdU was added $5 \mathrm{hr}$ after the $\left[{ }^{3} \mathrm{H}\right]$ thymidine pulse. However, when BrdU was added 12,24 , or $48 \mathrm{hr}$ after the $\left[{ }^{3} \mathrm{H}\right]$ thymidine pulse, only $11.3 \pm$ $3.7,8.0 \pm 1.8$, or $3.0 \pm 1.9 \%$, respectively, of cells were doubly positive. These data are consistent with the S-phase length of 18 hr at P0, as measured previously (Alexiades and Cepko, 1996). In vivo, $0 \%(0 / 155$ and $0 / 101 ; n=2)$ of $\left[{ }^{3} \mathrm{H}\right]$ thymidine heavily labeled cells were labeled by BrdU administration $48 \mathrm{hr}$ after the $\left[{ }^{3} \mathrm{H}\right]$ thymidine pulse. From these data, we conclude that, by the described criterion for heavily labeled, $>92 \%$ of heavily labeled cells have undergone their terminal S-phase by $24 \mathrm{hr}$ after the $\left[{ }^{3} \mathrm{H}\right.$ ] thymidine pulse, and $>97 \%$ by $48 \mathrm{hr}$.

Finally, the number of cells born on E17 in vivo that survived to $\mathrm{P} 1$ and $\mathrm{P} 15$ was approximated to be $2.69 \times 10^{5}$ and $2.11 \times 10^{5}$, respectively (see table in Fig. $2 A$ ). On the basis of these numbers and the number of postmitotic cells expected to be generated on
E17, $3.21 \times 10^{5}$ (Alexiades and Cepko, 1996), the percentage of cells surviving from E17 to P1 and from P1 to P15 was estimated to be $83 \%\left(2.69 \times 10^{5}\right.$ divided by $\left.3.21 \times 10^{5}\right)$ and $78 \%(2.11 \times$ $10^{5}$ divided by $2.69 \times 10^{5}$ ), respectively. The cell loss seen was therefore consistent with two reports on normal cell death (Young, 1984; Alexiades and Cepko, 1997). A third study on cell death in this period may have predicted a greater cell loss between P1 and P15 (Voyvodic et al., 1995). Regardless of this discrepancy, these data support the interpretation that the $\left[{ }^{3} \mathrm{H}\right]$ thymidine administration was nontoxic to the developing retina. Similar analyses of the results from other injection time points were also consistent with this interpretation (data not shown).

\section{Long average latency (6.5-7.0 d) between terminal S- phase and onset of rhodopsin expression in vivo}

The $\left[{ }^{3} \mathrm{H}\right]$ thymidine birthdating method was first used to measure the average lag between cell cycle withdrawal and the onset of rhodopsin expression for the total population of developing rods. To this end, the kinetics of cell cycle withdrawal and the onset of rhodopsin expression were initially analyzed independently for the population of developing rods. These measurements were then correlated to derive an average lag.

First, the $\left[{ }^{3} \mathrm{H}\right]$ thymidine birthdating method was applied to evaluate the overall kinetics of rod precursor genesis. Pregnant rats and neonatal littermates were injected with $\left[{ }^{3} \mathrm{H}\right]$ thymidine, 

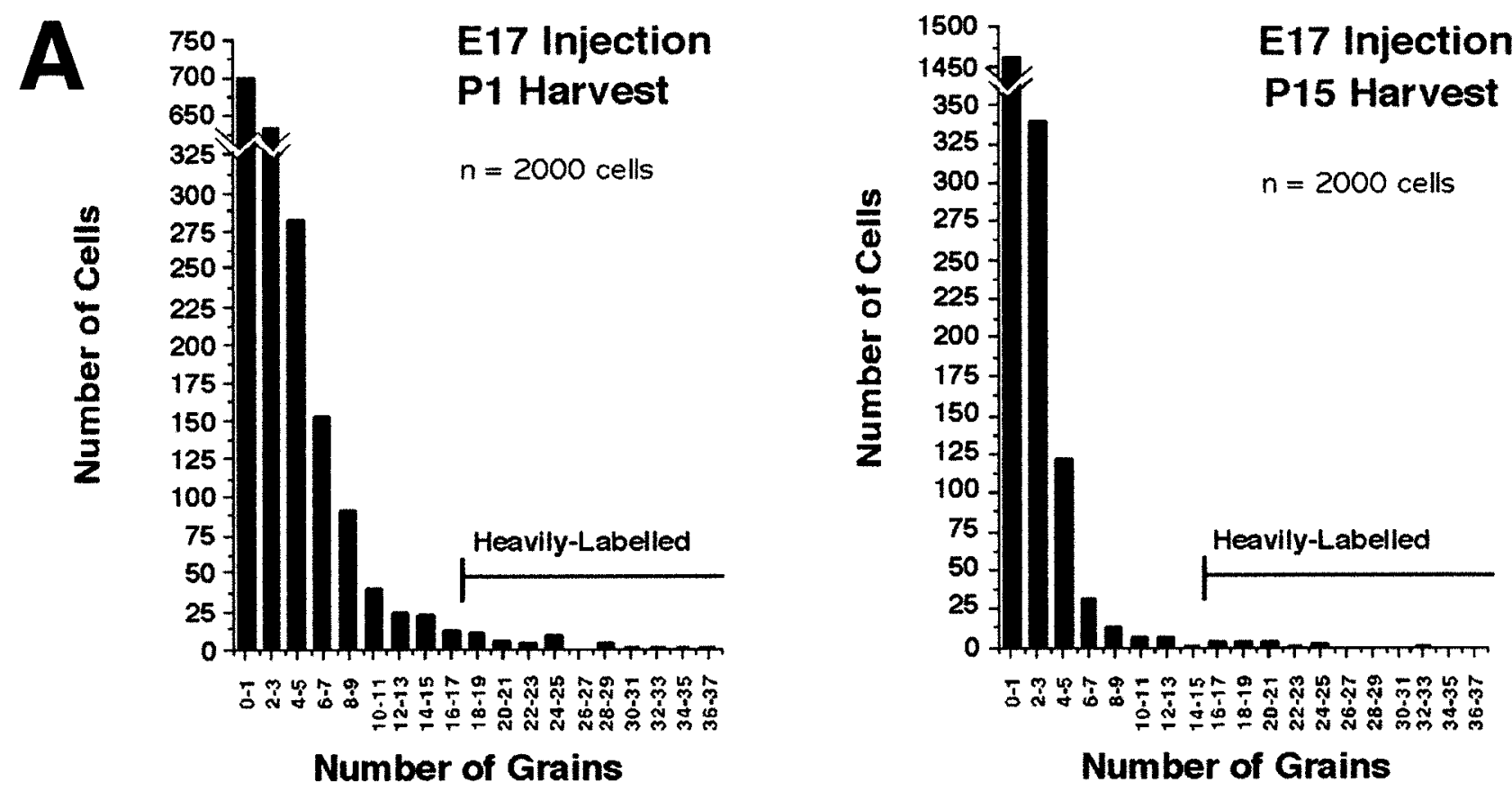

Measurement of Cells Born on E17 Surviving to P1 and P15

\begin{tabular}{|c|c|c|c|}
\hline Day of Harvest & $\begin{array}{c}\text { Percentage of Cells } \\
\text { Heavily-Labelled }\end{array}$ & $\begin{array}{c}\text { Number of Total } \\
\text { Cells / Retina }\end{array}$ & $\begin{array}{c}\text { Number of Heavily - } \\
\text { Labelled Cells } / \\
\text { Retina }\end{array}$ \\
\hline \hline P1 & $1.95 \%$ & $1.38 \times 10^{7}$ & $2.69 \times 10^{5}$ \\
\hline P15 & $0.85 \%$ & $2.48 \times 10^{7}$ & $2.10 \times 10^{5}$ \\
\hline
\end{tabular}

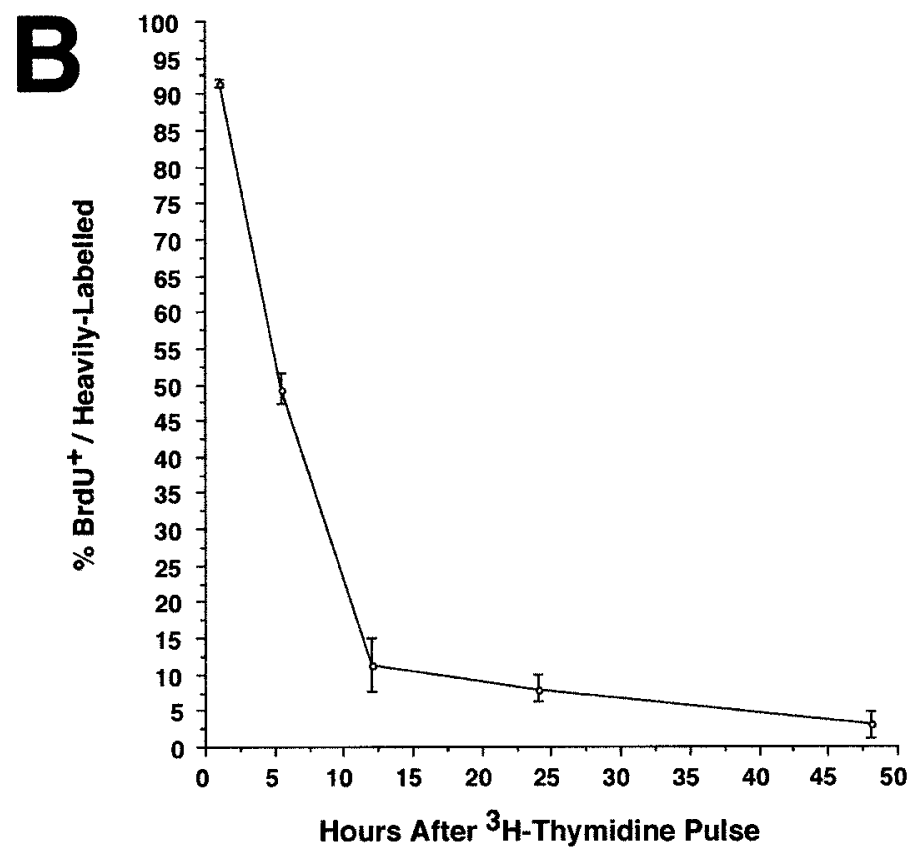

Figure 2. $\left[{ }^{3} \mathrm{H}\right]$ thymidine birthdating as a method for labeling retinal cells undergoing their terminal S-phase. $A$, Representative histograms displaying grain distributions in cells of retinae that were administered a pulse of $\left[{ }^{3} \mathrm{H}\right]$ thymidine at E17 in vivo and harvested at P1 or P15. The criterion for "heavily labeled" (as indicated) is defined as cells containing more than half the grain number of the most heavily labeled cell in an experiment. In the supporting table, the number of heavily labeled cells that survived to P1 and P15 was approximated. $B$, Cumulative BrdU labeling after $\left[{ }^{3} \mathrm{H}\right]$ thymidine pulse in vitro. $\mathrm{P} 0$ retinal explant cultures were administered a $1 \mathrm{hr}$ pulse of $\left[{ }^{3} \mathrm{H}\right]$ thymidine in vitro and then cumulatively labeled by addition of BrdU to cultures at 5, 12, 24, or $48 \mathrm{hr}$ after the $\left[{ }^{3} \mathrm{H}\right]$ thymidine pulse. Retinae were then examined after $4 \mathrm{~d}$ of culture for doubly labeled cells. Plotted are the percentages of $\left[{ }^{3} \mathrm{H}\right]$ thymidine heavily labeled cells that were positive for BrdU incorporation at the different times of addition. Each data point represents the average $\pm \operatorname{SEM}(n=4)$. More than 50 heavily labeled cells were scored per trial for each time point.

and the percentage of surviving cells born on the different injection days that ultimately differentiated as rods was determined using combined autoradiographic-immunocytochemical analysis on mature retinae. As shown in Figure $3 A$, rod precursors were generated as early as E14, when $5.0 \pm 0.4 \%$ of surviving cells differentiated as rods. The peak generation of rod precursors occurred between E21 and P2, when $78.3 \pm 8.0$ and $79.0 \pm 4.5 \%$, respectively, of surviving cells born on these days differentiated as 
rods. Rod precursor genesis continued into the late stages of the first postnatal week, when cell proliferation ceased entirely (Alexiades and Cepko, 1996).

The kinetics of onset of rhodopsin expression was analyzed over the full course of postnatal retinal development in vivo. To this end, a developmental series of freshly dissociated retinae was examined using the anti-rhodopsin antibody Rho4D2. Because rhodopsin protein expression closely mimics rhodopsin gene transcription (Treisman et al., 1988), measurements of the onset of rhodopsin immunoreactivity are likely to reflect upregulation of gene transcription. The kinetics of onset of immunocytochemically detectable rhodopsin in the postnatal retina are shown in Figure $3 B$. Interestingly, the onset of rhodopsin expression was found to be roughly biphasic. The percentage of rhodopsinpositive cells increased slowly from $<1 \%$ at $\mathrm{P} 1$ to $10.5 \pm 0.8 \%$ at P6 and then increased rapidly to $68.8 \pm 2.9 \%$ by P10. Ultimately, $71.6 \pm 2.5 \%$ of retinal cells were rod photoreceptors in the mature retina.

We used the percentage of rods born (Fig. 3A) and the number of cells born on each day of development (Alexiades and Cepko, 1996) to approximate the cumulative number of rod precursors born (Fig. 3C). Also, by multiplying the percentage of rhodopsinpositive cells (Fig. $3 B$ ) and the total number of retinal cells on each day of development (Alexiades and Cepko, 1996), we calculated the number of rhodopsin-positive cells per retina for each day of development (Fig. $3 C$ ). As shown in Figure 3C, the kinetics of rhodopsin onset closely mimics the kinetics of rod precursor genesis, separated by a 6-7 d lag. These data, summarized in Table 1, indicate that on the basis of an average for the total population of developing rods, rod precursors display a lag of $\sim 6.5-7.0 \mathrm{~d}$ between their terminal S-phase and the onset of rhodopsin expression.

\section{Rhodopsin onset is correlated temporally with terminal mitosis in postnatally born rod precursors}

We next set out to determine whether the duration of the latency between cell cycle withdrawal and rhodopsin onset was fixed or varied depending on the birthdate of the rod precursor. To investigate this question for postnatally born rods, the following experiment was performed. Neonatal littermates were administered single injections of $\left[{ }^{3} \mathrm{H}\right]$ thymidine on $\mathrm{P} 0, \mathrm{P} 2$, or P5 to label retinal precursor cells undergoing terminal $\mathrm{S}$-phases on these days. A developmental series of freshly dissociated retinae from these litters was then analyzed autoradiographically and for antirhodopsin immunoreactivity. The kinetics of onset of rhodopsin expression for cohorts of retinal cells born on each given day was thereby determined (Fig. $4 A-C$ ). Figure $4 D$ illustrates the kinetics of rhodopsin expression normalized for the percentages of rods ultimately found in each mature cohort.

Despite limited asynchrony within cohorts, rhodopsin onset in rod precursors born postnatally appeared to be strongly correlated temporally with the terminal mitosis. A fixed lag time for these cohorts was clearly demonstrated by comparing the lag to $50 \%$ final rhodopsin levels across postnatal cohorts: $5.65 \pm 0.27$, $5.97 \pm 0.01$, and $5.72 \mathrm{~d}$ for P0-, P2-, and P5-born cohorts, respectively. Table 2 summarizes the lag times to 10,50 , and $90 \%$ final rhodopsin levels for the postnatal cohorts.

\section{Early embryonically born rods show a variable lag and express rhodopsin synchronously with later-born cohorts}

Although rod precursors are born as early as E14, the number of immunocytochemically detectable rhodopsin-positive cells is very low in the early neonatal rat retina (Fig. 3). We therefore sought to characterize the relative timing of the terminal mitosis and the onset of rhodopsin expression in embryonically born rod precursors in vivo. To investigate this question, pregnant rats were administered single injections of $\left[{ }^{3} \mathrm{H}\right]$ thymidine on E15, E17, E19, or E21. A developmental series of freshly dissociated retinae from these litters was then analyzed as done previously for the postnatally born cohorts. Figure 5 illustrates the results of this experiment for the E17, E19, and E21 cohorts. Data for the E15 cohort is presented in Table 3. As shown in Figure $3 A, 10.5 \pm 0.5$, $16.9 \pm 0.1,65.0 \pm 8.0$, and $78.3 \pm 2.2 \%$ of surviving cells born on E15, E17, E19, and E21, respectively, were fated to differentiate as rods.

As shown in Figure $5 D$ and summarized in Table 4, the E19 and E21 cohorts displayed kinetics of rhodopsin onset similar to that of the postnatal cohorts. The E19 and E21 cohorts displayed a lag of $\sim 6.10 \pm 0.07$ and $6.54 \pm 0.00 \mathrm{~d}$, respectively, to $50 \%$ of final levels of rhodopsin. The E15 and E17 cohorts, however, appeared to display different kinetics. For the E17 cohort, the lag to $50 \%$ of the final level of rhodopsin-positive cells was $8.24 \pm$ $0.30 \mathrm{~d}$, longer than the lag of 5.5 to $6.5 \mathrm{~d}$ for the later-born rod precursors. For the E17-born rods, $50 \%$ of the final level of rhodopsin-positive cells were detected on P3.74 \pm 0.30 , which was synchronous with the E19 cohort that was born $2 \mathrm{~d}$ later and reached $50 \%$ final levels at P3.60 \pm 0.07 (Fig. 5D). The E15 cohort had an even longer lag than the E17 cohort, averaging $\sim 12.5 \mathrm{~d}$ (Tables 3, 4). Similarly, for the E15-born cohort, rhodopsin onset also appeared approximately synchronous with laterborn rod precursors. The lag times to 10,50 , and $90 \%$ final rhodopsin levels are summarized for the embryonically born cohorts in Table 4.

\section{Culturing E16-born cells with excess P0 cells does not alter lag to rhodopsin or change percentage of E16 cells differentiating as rods}

As described above, early embryonically born precursors displayed a long lag to rhodopsin onset and a low frequency of rod differentiation relative to postnatally born precursors. To examine whether this is intrinsically programmed or whether it can be influenced by environmental factors, we performed experiments similar to those conducted by Watanabe and Raff (1990). As outlined in Figure $6 A$, intact E16 retinal explants were pulselabeled with $\left[{ }^{3} \mathrm{H}\right]$ thymidine in vitro and then dissociated and reaggregated with a 20-fold excess of unlabeled E16 retinal cells or $\mathrm{P} 0$ retinal cells. The reaggregate pellets were cultured for 3,5 , 7, 10, 12, 15, or $17 \mathrm{~d}$, at which point rod differentiation was completed. At each of these time points, the heavily labeled cells, or cells in their terminal S-phase in the explant, were scored for rhodopsin expression.

When $\left[{ }^{3} \mathrm{H}\right]$ thymidine-labeled E16 cells were reaggregated with other E16 cells, $0.00 \pm 0.00 \%(0 / 500)$ of cells born in the E16 explant expressed rhodopsin after $5 \mathrm{~d}$ (Fig. 6B). The first cells born on E16 that expressed detectable rhodopsin were observed after $10 \mathrm{~d}$ in vitro. After rhodopsin expression had reached a plateau at $17 \mathrm{~d}$ in vitro, $21.67 \pm 4.08 \%$ of the cells born on E16 expressed rhodopsin. For cells born on $\mathrm{P} 0$ and reaggregated with other P0 cells, the first rhodopsin-positive cells were present after $3 \mathrm{~d}$ in vitro. Of such cells, $25.13 \pm 5.92 \%$ expressed rhodopsin by $5 \mathrm{~d}$ in culture, and $67.00 \pm 3.65 \%$ of such cells expressed rhodopsin by $17 \mathrm{~d}$ in culture (Fig. $6 \mathrm{~B}$ ). The kinetics and plateau levels of rhodopsin expression roughly mimicked those observed for cells in vivo as presented above. 
A

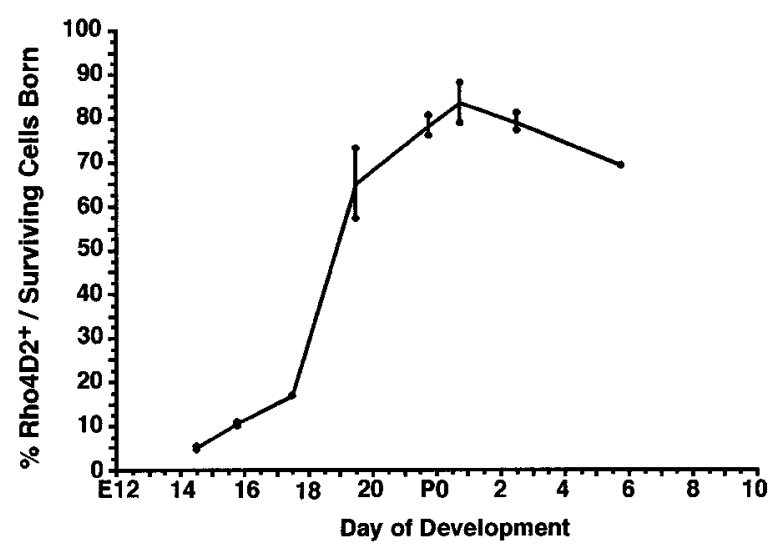

B

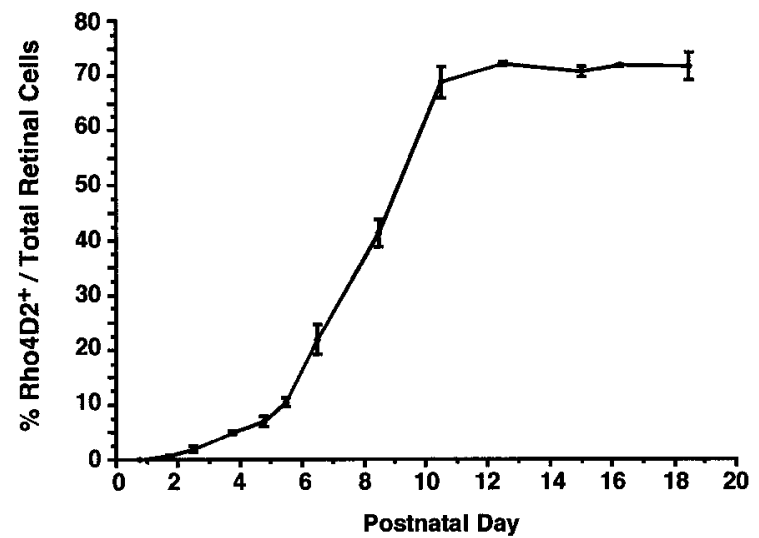

C

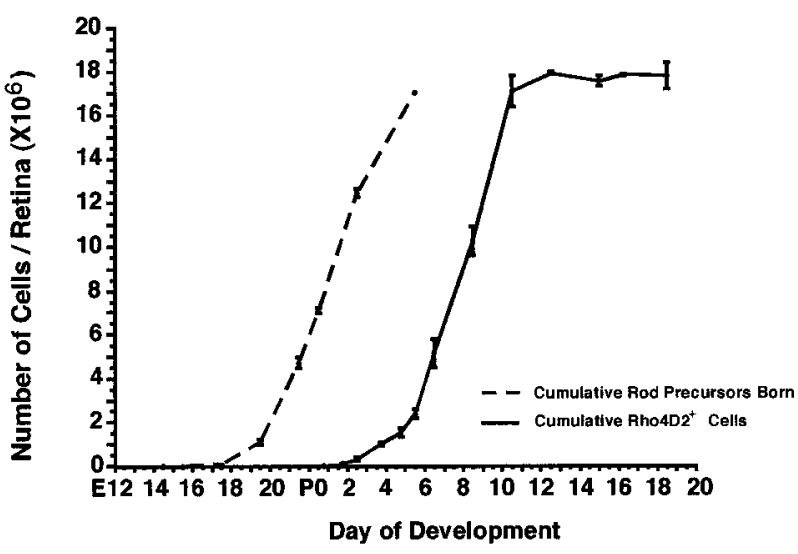

Figure 3. Overall kinetics of rod precursor genesis correlated with kinetics of rhodopsin onset. $A$, Rod precursor genesis in developing rat retina. Developing retinae were administered a $\left[{ }^{3} \mathrm{H}\right]$ thymidine pulse in vivo on E14, E15, E17, E19, E21, P0, P2, or P5. The percentage of surviving cells born on each day of injection that differentiated as rod photoreceptors was assessed using combined immunocytochemical-autoradiographic analysis on mature retinae. $B$, Kinetics of rhodopsin expression in neonatal retina and kinetics of onset of immunocytochemically detectable rhodopsin expression in the postnatal rat retina. Plotted are the percentages of cells per retina positive for Rho4D2 staining during postnatal development. $C$, The kinetics of rhodopsin onset closely mimic the kinetics of rod precursor genesis separated by a 6.5-7.0 d lag. We used the data in $A$ and $B$ and the number of total retinal cells and postmitotic cells generated on each day of retinal development (Alexiades and Cepko, 1996) to approximate the cumulative numbers of rod precursors born and rhodopsin-positive cells for each day of retinal development.
Table 1. The average lag between terminal S-phase and onset of rhodopsin is 6.5-7.0 d for the total population of developing rods

Number of

\begin{tabular}{|c|c|c|c|}
\hline $\begin{array}{l}\text { Number of } \\
\text { rods } \times 10^{7} \\
(\% \text { final rods })\end{array}$ & $\begin{array}{l}\text { Day by which } \\
\text { rods are born }\end{array}$ & $\begin{array}{l}\text { Day by which rods } \\
\text { are rhodopsin- } \\
\text { positive }^{b}\end{array}$ & $\begin{array}{l}\text { Lag } \\
\text { time (d) }\end{array}$ \\
\hline $0.178(10)$ & $\mathrm{E} 20.2 \pm 0.18$ & $\mathrm{P} 4.9 \pm 0.19$ & $6.7 \pm 0.37$ \\
\hline $0.444(25)$ & $\mathrm{E} 21.3 \pm 0.09$ & $\mathrm{P} 6.2 \pm 0.26$ & $6.9 \pm 0.35$ \\
\hline $0.888(50)$ & $\mathrm{P} 1.1 \pm 0.05$ & $\mathrm{P} 7.8 \pm 0.26$ & $6.7 \pm 0.31$ \\
\hline $1.332(75)$ & $\mathrm{P} 2.6^{*}$ & $\mathrm{P} 9.3 \pm 0.20$ & $6.7 \pm 0.20$ \\
\hline $1.599(90)$ & $\mathrm{P} 3.4^{*}$ & $\mathrm{P} 10.0 \pm 0.20$ & $6.6 \pm 0.20$ \\
\hline
\end{tabular}

The above data are derived from Figure $3 C$, where the cumulative numbers of rod precursors born and rhodopsin-positive precursors were approximated for each day of retinal development. From these data, the lag between rod precursor genesis and onset of rhodopsin expression was determined. Each data point represents the average \pm SEM, except where indicated.

${ }^{a}$ In this column, data were derived from $n=2$, except where indicated by an asterisk $(*)$ where a single trial was performed.

${ }^{b}$ In this column, data were derived from $n=2-6$.

When cells born on E16 cells were reaggregated with an excess of unlabeled P0 cells, the percentage of birthdated E16 cells expressing rhodopsin was largely unaltered relative to controls at all time points examined. As shown, $0.00 \pm 0.00 \%(0 / 500)$ of cells initiating their terminal S-phase in E16 explants expressed rhodopsin after $5 \mathrm{~d}$ in vitro with excess $\mathrm{P} 0$ cells, compared with $0.00 \pm$ $0.00 \%$ for such cells cultured with an excess of other E16 cells (Fig. 6B). Again, the first cells born on E16 to become rhodopsinpositive were not detected until $10 \mathrm{~d}$ in vitro, despite the fact that cells from the $\mathrm{P} 0$ retina were beginning to express rhodopsin before this point (data not shown). After rod differentiation was completed in culture at $17 \mathrm{~d}$ in vitro, $23.33 \pm 3.52 \%$ of cells born on E16 expressed rhodopsin when cultured with P0 cells versus $21.67 \pm 4.08 \%$ when cultured with other E16 cells. To exclude the possibility that a 20 -fold excess of $\mathrm{P} 0$ cells was not sufficient to influence the E16 cells, E16 retinal explants were pulse-labeled with $\left[{ }^{3} \mathrm{H}\right]$ thymidine in vitro and then dissociated and reaggregated with a 50 -fold excess of unlabeled $\mathrm{P} 0$ cells. In such reaggregates, $17.20 \%$ (16/93) of the E16 birthdated cells expressed rhodopsin after $17 \mathrm{~d}$ in vitro. The different behavior exhibited by the E16 and P0 cells in vitro was not caused by the separation of the two populations in the pellets. The E16 cells remained well distributed during the formation of the reaggregate (Fig. $6 C$ ) and remained distributed during the culture period (Fig. 6D). Moreover, within the mixed pellets, birthdated P0 cells expressed rhodopsin with kinetics similar to that seen for P0 cells in P0 reaggregates (data not shown). We conclude, therefore, that cells born on E16 were not influenced by the environmental signals created by an excess of $\mathrm{P} 0$ cells with respect to both the onset of rhodopsin expression and the percentage of such cells differentiating as rods.

\section{DISCUSSION}

We have conducted a comprehensive analysis of the relative timing of the terminal mitosis and the onset of rhodopsin expres-

(The estimation of the cumulative number of rod precursors born neglects cell death and therefore may be a slight overestimate for the earlier time points in particular.) The plot lines for $A$ and for rod precursor birth in $C$ represent the average of two trials, and the error range extends to the values of each individual trial, with the exception of $\mathrm{P} 5$ where a single trial was performed. One hundred or more heavily labeled cells were scored for each data point for these curves. In $B$ and for the number of rhodopsin-positive cells in $C$, each plotted value represents the average \pm SEM. More than 250 cells per trial were scored, with between two and six trials per time point. 
A

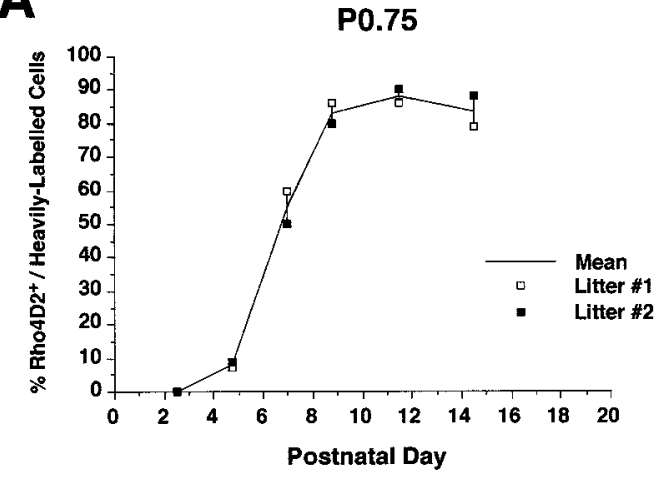

B

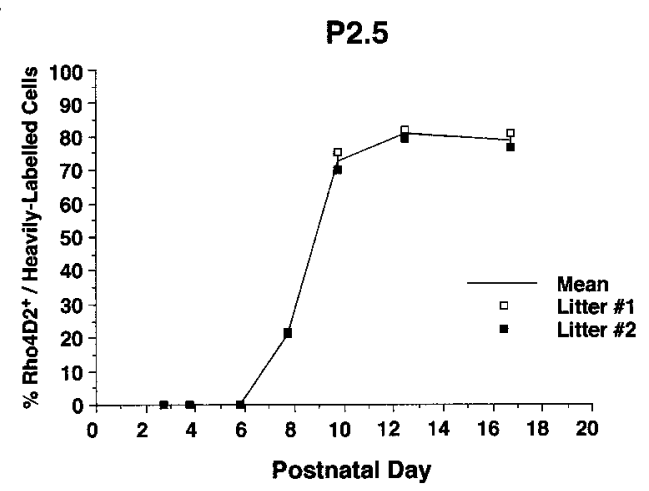

C

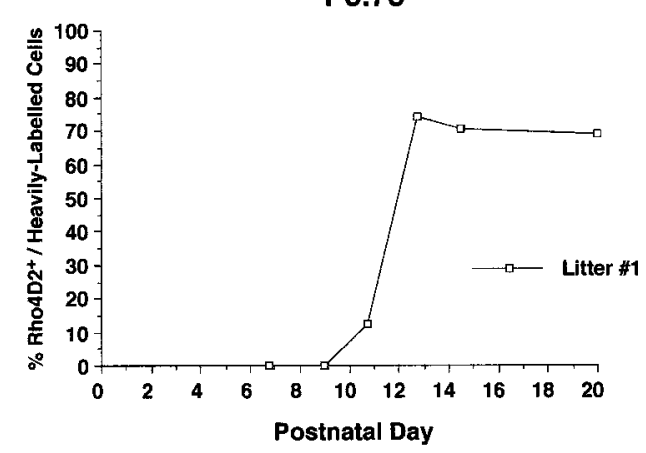

D

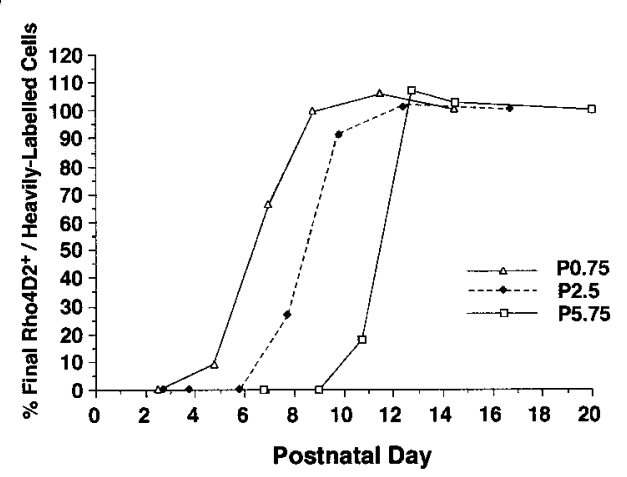

Figure 4. Kinetics of onset of rhodopsin expression in retinal cohorts born postnatally. Neonatal litters were administered $\left[{ }^{3} \mathrm{H}\right]$ thymidine by intraperitoneal injection on $\mathrm{P} 0, \mathrm{P} 2$, or P5 to label retinal precursor cells undergoing terminal S-phases on these days. A developmental series of freshly dissociated retinae from these litters was then analyzed auto-

\begin{tabular}{|c|c|c|c|}
\hline $\begin{array}{l}\text { Day of birth of } \\
\text { rod precursors }\end{array}$ & $\begin{array}{l}\% \text { Final } \\
\text { rhodopsin }\end{array}$ & Postnatal day & $\begin{array}{l}\text { Lag time from ter } \\
\text { minal mitosis }(d)\end{array}$ \\
\hline \multirow[t]{3}{*}{$\mathrm{P} 0.75$} & 10 & $\mathrm{P} 4.74 \pm 0.04$ & $3.99 \pm 0.04$ \\
\hline & 50 & $\mathrm{P} 6.40 \pm 0.27$ & $5.65 \pm 0.27$ \\
\hline & 90 & $\mathrm{P} 7.74 \pm 0.48$ & $6.99 \pm 0.48$ \\
\hline \multirow[t]{3}{*}{$\mathrm{P} 2.5$} & 10 & $\mathrm{P} 6.50 \pm 0.01$ & $4.00 \pm 0.01$ \\
\hline & 50 & $\mathrm{P} 8.47 \pm 0.01$ & $5.97 \pm 0.01$ \\
\hline & 90 & $\mathrm{P} 9.70 \pm 0.03$ & $7.2 \pm 0.03$ \\
\hline \multirow[t]{3}{*}{ P5.75 } & 10 & P9.97 & 4.22 \\
\hline & 50 & P11.47 & 5.72 \\
\hline & 90 & $\mathrm{P} 12.36$ & 6.61 \\
\hline
\end{tabular}

Neonatal litters were administered ${ }^{3} \mathrm{H}$-thymidine on $\mathrm{P} 0, \mathrm{P} 2$, or $\mathrm{P} 5$ to label retinal precursor cells undergoing terminal S-phases on these days. A developmental series of freshly dissociated retinae from these litters was then analyzed by combined immunocytochemical-autoradiographic analysis. Each data point represents the average \pm SEM where $n=2$, except for P5, where a single trial was performed. Data are derived from Figure $4 D$.

sion in the rat retina in vivo. Our results demonstrate that there are two distinct phases of rod development during the histogenesis of the rat retina in vivo: an early phase and a late phase. Figure 7 summarizes our interpretation of the results from the in vivo analysis. Most rod precursors participate in the late phase of rod genesis, are born after E19, and display remarkable regularity in the onset of rhodopsin expression. These rod precursors initiate rhodopsin expression 5.5-6.5 d on average after their terminal mitosis. By contrast, for early-phase rod precursors, i.e., those born before E19, the lag between the terminal mitosis and the onset of rhodopsin expression was measured to be significantly longer, averaging from 8.5 to $12.5 \mathrm{~d}$. These early-born rod precursors seemed to initiate rhodopsin expression in a manner that was not correlated temporally with the terminal mitosis. For these cells, onset of rhodopsin expression appeared approximately synchronous with the later-born cells, suggesting a synchronous recruitment to the rod cell fate controlled by environmental signals. To examine this possibility, we conducted heterochronic cell mixing experiments and examined effects on the kinetics of rhodopsin onset and induction to the rod cell fate in early-born precursors exposed to a late retinal environment. In these experiments, we demonstrate, similar to previous studies (Watanabe and Raff, 1990), that the delay between the terminal mitosis and rhodopsin expression in early-born rod precursors is not shortened by exposing these early cells to a late environment using a reaggregate culture system. Furthermore, in contrast to the conclusions drawn in the previous report, we conclude here that the percentage of early-born precursors adopting the rod cell fate is also unaltered when these cells are transplanted to a late environment in vitro (see below). These in vitro experiments thereby suggest that the early-phase rod precursors are intrinsically distinct from the late-phase precursors with respect to both the kinetics of rhodopsin synthesis and the ability to produce rod photoreceptors.

radiographically and for anti-rhodopsin immunoreactivity. $A, \mathrm{P} 0.75 ; B$, $\mathrm{P} 2.5$; $C$, P5.75. D, Co-plot of kinetics for P0.75, P2.5, and P5.75, normalized for the percentages of rods ultimately found in each mature cohort. The plot line represents the average of two trials for each time point. For $A$ and $B$, the error range extends to the values of each individual trial. 
A

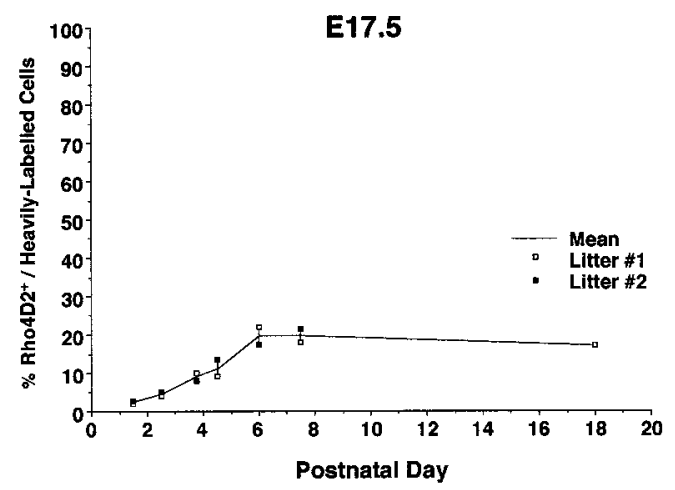

B

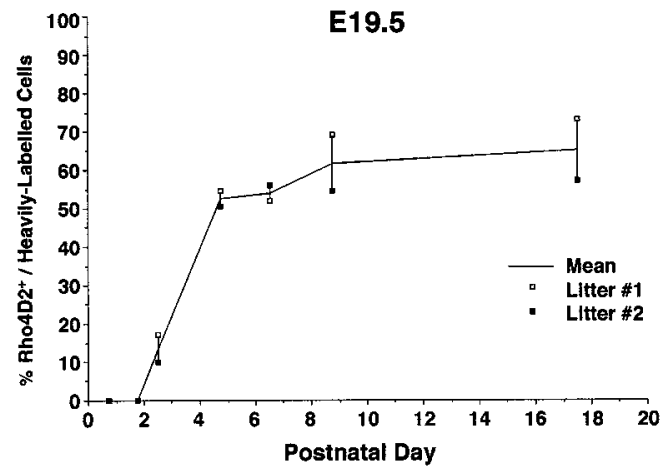

C

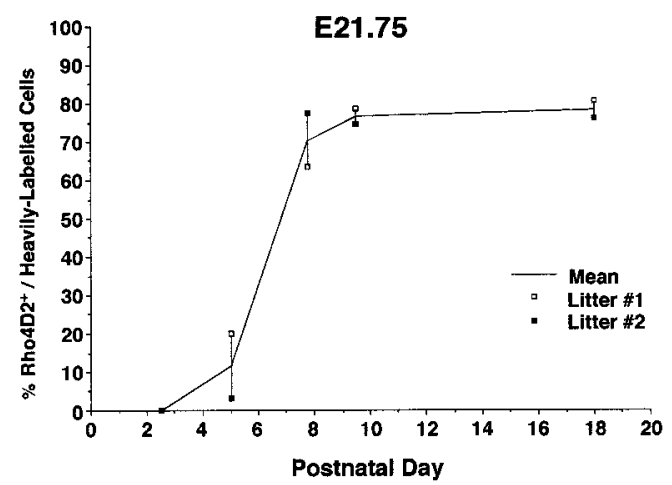

D

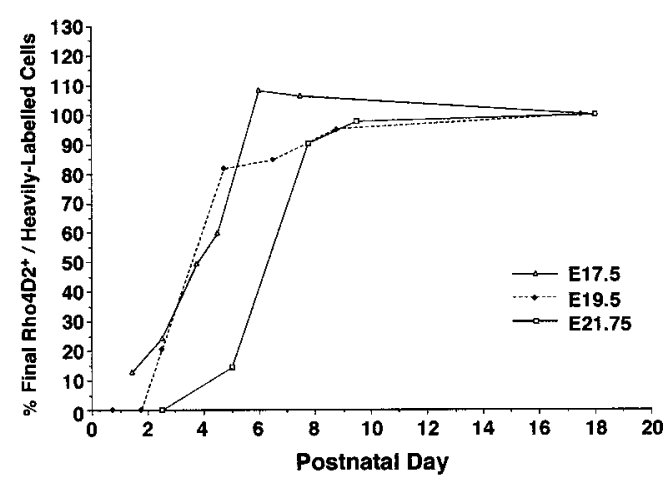

Figure 5. Kinetics of onset of rhodopsin expression in retinal cohorts born embryonically. Pregnant rats were administered single injections of $\left[{ }^{3} \mathrm{H}\right]$ thymidine on E17, E19, and E21 to label retinal precursor cells undergoing terminal S-phases on these days. A developmental series of freshly dissociated retinae from these litters was then analyzed auto-

\begin{tabular}{|c|c|c|}
\hline \multicolumn{3}{|c|}{$\begin{array}{l}\text { Table 3. Kinetics of onset of rhodopsin expression in retinal cohort } \\
\text { born E15 }\end{array}$} \\
\hline Postnatal day & $\begin{array}{l}\text { Number Rho4D2+/ } \\
\text { total heavily labeled } \\
\text { scored }(\%) \text { Trial } 1\end{array}$ & $\begin{array}{l}\text { Number Rho4D2+/ } \\
\text { total heavily labeled } \\
\text { scored }(\%) \text { Trial } 2\end{array}$ \\
\hline $\mathrm{P} 1.75$ & $0 / 100(0)$ & ND \\
\hline $\mathrm{P} 2.5$ & $0 / 100(0)$ & ND \\
\hline P3.75 & $0 / 100(0)$ & ND \\
\hline P4.75 & $\mathrm{ND}$ & $0 / 100(0)$ \\
\hline P5.5 & $0 / 74(0)$ & ND \\
\hline P6.5 & $8 / 103(7.8)$ & ND \\
\hline P10.5 & $11 / 91(12.1)$ & ND \\
\hline P19.0 & $11 / 100(11)$ & $10 / 100(10)$ \\
\hline
\end{tabular}

Pregnant rats were administered single injections of ${ }^{3} \mathrm{H}$-thymidine at E15.75 to label retinal precursor cells undergoing terminal S-phases at this time. A developmental series of freshly dissociated retinae from these litters was then analyzed autoradiographically and for anti-rhodopsin immunoreactivity. ND indicates a trial timepoint that was not scored.

Table 4. Timing of rhodopsin onset in early embryonic-born precursor appears approximately synchronous with later-born cohorts

\begin{tabular}{llll}
$\begin{array}{l}\text { Day of birth of } \\
\text { rod precursors }\end{array}$ & $\begin{array}{l}\text { \% Final } \\
\text { rhodopsin }\end{array}$ & Postnatal day & $\begin{array}{l}\text { Lag time from ter- } \\
\text { minal mitosis (d) }\end{array}$ \\
\hline E15.75 & 10 & P5.64 & 11.89 \\
& 50 & P6.21 & 12.46 \\
& 90 & P8.45 & 14.7 \\
E17.5 & $13.4 \pm 1.6$ & P1.5 & 6.0 \\
& 50 & P3.74 \pm 0.30 & $8.24 \pm 0.30$ \\
E19.5 & 90 & P5.74 \pm 0.51 & $10.24 \pm 0.51$ \\
& 10 & P2.13 \pm 0.06 & $4.63 \pm 0.06$ \\
& 50 & P3.60 \pm 0.07 & $6.1 \pm 0.07$ \\
E21.75 & 90 & P6.64 \pm 1.68 & $9.15 \pm 1.68$ \\
& 10 & P4.34 \pm 0.83 & $4.59 \pm 0.83$ \\
& 50 & P6.29 \pm 0.00 & $6.54 \pm 0.00$ \\
& 90 & P8.12 \pm 0.70 & $8.37 \pm 0.70$
\end{tabular}

Pregnant rats were administered single injections of ${ }^{3} \mathrm{H}$-thymidine on E15, E17, E19, or E21. A developmental series of freshly dissociated retinae from these litters was then analyzed by combined immunocytochemical-autoradiographic analysis. Each data point represents the average \pm SEM where $n=2$, except for E15, for which a single trial was performed. Data are derived from Figure $5 D$ and Table 3.

\section{Long latency and temporal correlation between rhodopsin onset and cell cycle withdrawal for the majority of rods in vivo}

A long delay between photoreceptor birthdays and opsin expression appears well conserved across many species (for review, see Cepko, 1996). Previous studies in mouse and rat have measured the time between BrdU labeling and the first $\mathrm{BrdU}^{+}$, rhodopsin ${ }^{+}$ cells to be 48-54 hr in neonatal rod precursors (Watanabe and Raff, 1990; Liou et al., 1994). It should be noted that the data presented here do not differ from these previous observations. For example, as shown in Figure $4 A$, the first P0-born rod precursors express rhodopsin between 2 and $3 \mathrm{~d}$ after their terminal S-phase. The measurement of 5.5-6.5 d represents instead the

radiographically and for anti-rhodopsin immunoreactivity. $A, \mathrm{E} 17.5 ; B$, E19.5; C, E21.75. D, Co-plot of kinetics for E17.5, E19.5, and E21.75, normalized for the percentages of rods ultimately found in each mature cohort. The plot line represents the average of two trials for each time point. For $A-C$, the error range extends to the values of each individual trial. 

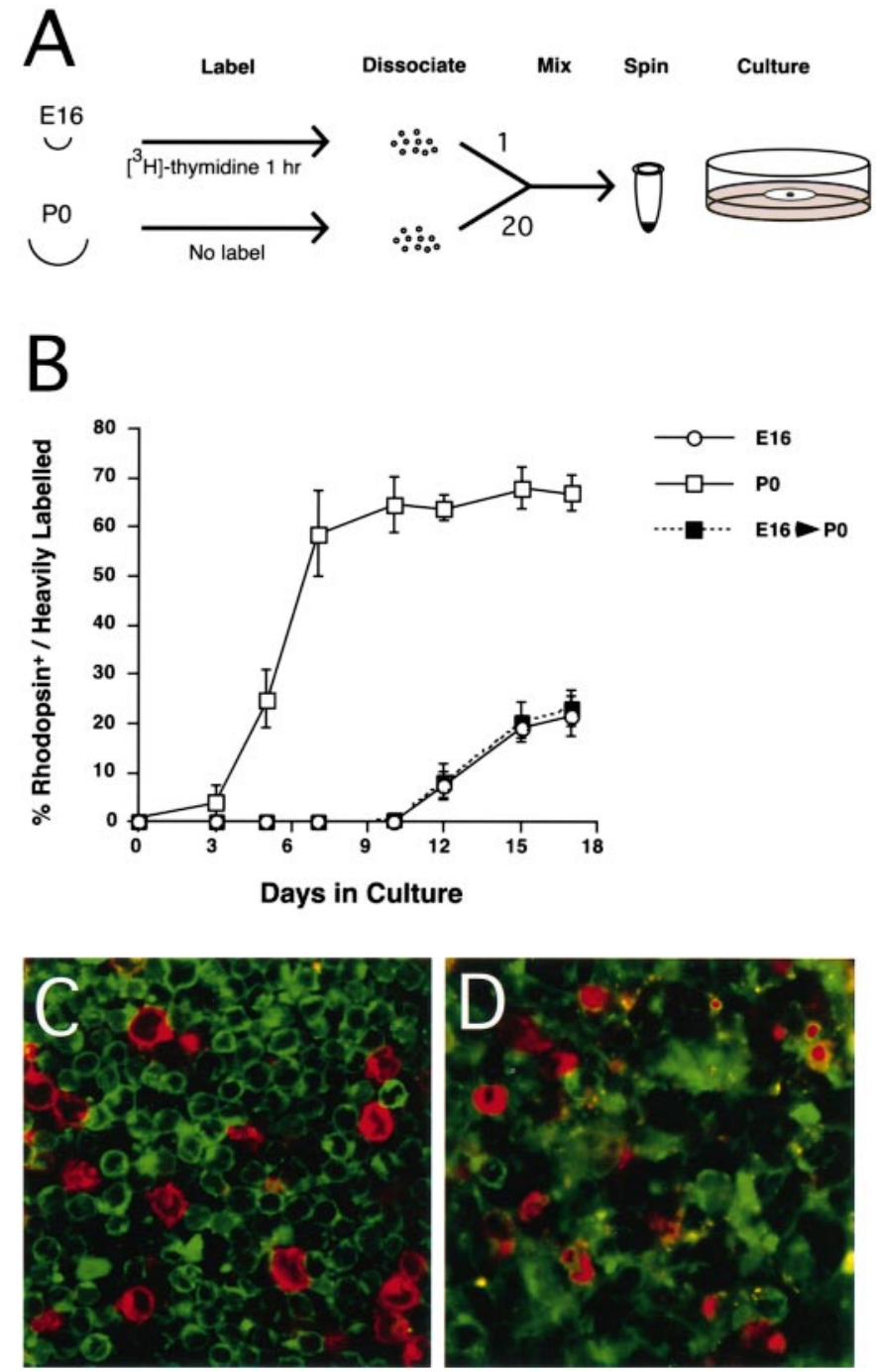

Figure 6. Culturing embryonically born cells with excess postnatal cells does not alter lag to rhodopsin or change percentage of embryonic cells differentiating as rods. $A$, Outline of protocol for mixed reaggregate experiments (see Materials and Methods). $B$, Kinetics of rhodopsin expression in reaggregates of E16-born cells cultured alone $(\bigcirc)$, P0-born cells cultured alone $(\square)$, or E16-born cells cultured with a 20 -fold excess of $\mathrm{P} 0$ retinal cells $(\boldsymbol{\square})$. C, $D$, Confocal images of reaggregates cultured for $1 \mathrm{hr}(C)$ or $5 \mathrm{~d}(D)$. E16 cells are labeled with PKH-26 dye and are depicted in red; $\mathrm{P} 0$ cells are labeled with $\mathrm{PKH}-2$ dye and are depicted in green. $C$ is one optical slice, and $D$ is a composite of 16 optical slices covering $10 \mu \mathrm{M}$ in the $z$-axis.

average, or median lag, for these late born rods. Because $80 \%$ of such rods begin to express rhodopsin between 4 and $7 \mathrm{~d}$ after the terminal mitosis, we believe that the average lag is a more informative measurement for studying these rods than is the lag to the first rhodopsin-expressing cells. Furthermore, the present report is the first demonstration of the strong temporal correlation in rat between the terminal mitosis and rhodopsin onset for the majority of rod precursors in rodent retinal development.

\section{Distinct kinetics of rhodopsin onset for early- and late-born rods in vivo}

The early-born rods display apparently distinct kinetics of rhodopsin onset relative to the terminal mitosis. For cohorts born on E15 and E17, rhodopsin onset becomes measurable only after a lag of significantly longer than $6.5 \mathrm{~d}$ (Table 4). The onset of rhodopsin in cohorts born before E19 appears roughly synchronous with the onset of rhodopsin expression in later-born cohorts. These data suggest that cohorts born earlier than E19 wait longer than $6.5 \mathrm{~d}$ to initiate opsin expression and that this onset is roughly synchronous with later-born cohorts. However, an alternative interpretation involving differential cell death should be considered. There is a formal possibility that the E15 and E17 cohorts may follow similar kinetics of rhodopsin onset relative to their terminal mitosis as is followed by the postnatal cohorts (i.e., a 5.5-6.5 d lag). These kinetics may be masked to our measurements until a massive cell death of nonrods occurs in the postnatal period. However, $>90 \%$ differential cell death would be required to shorten the observed long lags to 5.5-6.5 d. At this time, existing data argues against this interpretation, because all approximations of differential cell death in the early postnatal period are estimated to be far lower than 90\% (Young, 1984; Voyvodic et al., 1995; Alexiades and Cepko, 1997). For example, $20 \%$ amacrine cell death was found during the P2-P11 interval, and amacrine cells constitute a significant fraction of nonrods born on E15 and E17 (Alexiades and Cepko, 1997). As well, cell loss between P1 and P15 for the E17 cohort was found to be $\sim 22 \%$ (Fig. $2 A$, see supporting table). On the basis of these measurements, therefore, the longer lag seen for the early embryonically born cohorts is unlikely to be attributable to cell death alone.

\section{Early and late precursors appear intrinsically distinct in vitro}

Early-born precursors and late-born precursors differ with respect to the frequency that these cells choose the rod cell fate in vivo. For example, $\sim 5 \%$ of surviving cells born on E14 differentiate as rods, as compared with $\sim 80 \%$ on $\mathrm{P} 2$ (Fig. $3 A$ ). As well, as discussed above, the early-born precursors demonstrate a significantly longer lag to rhodopsin expression relative to the laterborn cells in vivo. In a study by Watanabe and Raff (1990), the onset of rhodopsin expression in a population of cells that were labeled with BrdU at E15 was similarly found to be delayed relative to a population that was labeled on $\mathrm{P} 1$ in vitro. These investigators tested whether the long lag observed for E15 labeled cells was extrinsically or intrinsically programmed by conducting heterochronic cell-mixing experiments in vitro. They argued that the longer delay seen for E15 cells was intrinsically programmed because mixing E15 cells with excess P1 cells did not speed the onset of rhodopsin in the E15 cells. The results presented here confirm these original observations and are consistent with a cell-autonomous inhibitor of rod differentiation acting in these cells.

In contrast to the conclusions drawn here, Watanabe and Raff (1990) concluded that exposing E15 cells to the P1 environment resulted in a 40-fold increase in E15 precursors adopting the rod cell fate. The basis for this conclusion was an increase from $0.008 \pm 0.002$ to $0.44 \pm 0.05 \%$ of E15 cells that were rhodopsinpositive after $6 \mathrm{~d}$ in vitro with an excess of P1 cells (Watanabe and Raff, 1990). Despite their conclusion, because their cultures were not followed to the completion of rhodopsin expression, one is unable to distinguish between an acceleration in rhodopsin kinetics in a small subset of E15 cells at $6 \mathrm{~d}$ in vitro and an overall increase in recruitment to the rod cell fate. In the current study, the cultures were followed to plateau levels of rhodopsin expression in vitro, and no alteration in the percentage of early-born rod precursors expressing rhodopsin was observed. We therefore conclude that the vast majority of early-born precursors are not 

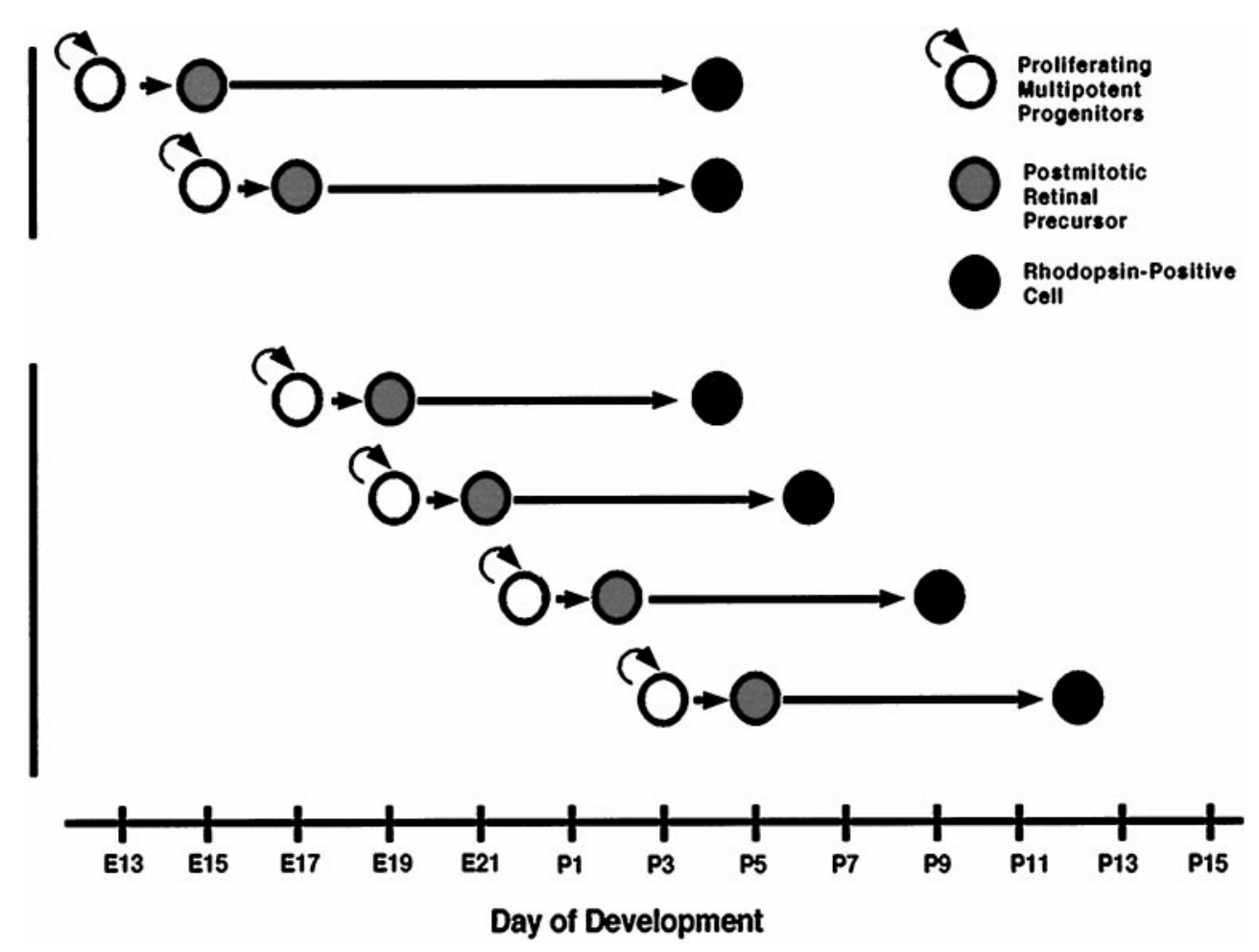

Figure 7. Two distinct phases of rod development in vivo. Rod genesis is divided into two phases in vivo: an early phase and a late phase. Depicted schematically are the time lags from the terminal mitosis of rod precursors to the $50 \%$ final rhodopsin level for cohorts born from E15 through P5. For a majority of rod precursors, those born after E19, the timing of rhodopsin onset is tightly linked to the timing of cell cycle withdrawal. For these cohorts, the steps leading from the terminal mitosis to rhodopsin expression take an average 5.5-6.5 d. These cells constitute the late phase of rod genesis. During the early phase of rod genesis, those cells born before E19 appear to display lags significantly longer than $6.5 \mathrm{~d}$, and commence rhodopsin expression approximately synchronously with the late phase cells in the early postnatal period.

influenced with respect to commitment to the rod cell fate when exposed to a late environment in vitro.

The possibility that E16-born cells continue to be influenced by signals derived from other E16 cells in the heterochronic pellets cannot be formally excluded. However, when examined after $5 \mathrm{~d}$ in vitro, the E16 cells remained well dispersed and were surrounded by a majority of P0-derived cells (Fig. 6D) (Watanabe and Raff, 1990). These observations lead us to favor the interpretation that the environment seen by the E16-born cells and that of the P0-born control cells are highly similar. Despite being placed in similar environments, these two cell populations display distinct behaviors with respect to both rod genesis and the kinetics of rhodopsin expression as discussed above. These observations therefore suggest that the E16-born precursors and the P0-born precursors are intrinsically distinct.

\section{Characterizing the steps in rod development}

For the majority of rod precursors, the onset of rhodopsin expression is temporally correlated with cell cycle withdrawal, yet a long latency, 5.5-6.5 d, is required to execute the steps leading from a multipotent progenitor to a rhodopsin-expressing cell. What are the steps leading from cell cycle arrest to rhodopsin expression that require 5.5-6.5 d? There are presently several candidate genes that may be involved in some of these steps. Among these are Notch and HES-1, both of which have been shown to be inhibitors of neuronal differentiation including rod differentiation (Dorsky et al., 1995; Tomita et al., 1996; Bao and Cepko, 1997). As well, Pax-6 and Chx-10 are both expressed in retinal progenitor cells and ultimately become restricted to nonphotoreceptor cell types late in development (Liu et al., 1994;
Hitchcock et al., 1996). These genes, therefore, are also good candidates as inhibitors of rod differentiation. Finally, a recently discovered paired-type homeobox gene, Crx, is photoreceptorspecific and activates transcription from regulatory elements of photoreceptor-specific genes in vitro (Chen et al., 1997; Furukawa et al., 1997). Crx is, therefore, a candidate promoter of rod differentiation. The data presented in the current report now provide a framework in which to order the activity of these important molecules and others in the pathway that leads a postmitotic retinal precursor to a committed rhodopsinexpressing cell.

\section{REFERENCES}

Alexiades MR, Cepko C (1996) Quantitative analysis of proliferation and cell cycle length during development of the rat retina. Dev Dyn 205:293-307.

Alexiades MR, Cepko C (1997) Subsets of retinal progenitors display temporally regulated and distinct biases in the fates of their progeny. Development 124:1119-1131.

Altshuler D, Cepko C (1992) A temporally regulated, diffusible activity is required for rod photoreceptor development in vitro. Development 114:947-957.

Altshuler D, LoTurco JJR, Cepko CL (1993) Taurine promotes the differentiation of a vertebrate retinal cell type in vitro. Development 119:1317-1328.

Arimatsu Y, Nihonmatsu I, Hirata K, Takiguchi-Hayashi K (1994) Cogeneration of neurons with a unique molecular phenotype in layers $\mathrm{V}$ and VI of widespread lateral neocortical areas in the rat. J Neurosci 14:2020-2031.

Bao ZZ, Cepko CL (1997) The expression and function of Notch pathway genes in the developing rat eye. J Neurosci 17:1425-1434.

Belecky-Adams T, Cook B, Adler R (1996) Correlations between terminal mitosis and differentiated fate of retinal precursor cells in vivo and 
in vitro: analysis with the "window-labeling" technique. Dev Biol 178:304-315

Carter-Dawson LD, LaVail MM (1979) Rods and cones in the mouse retina. II. Autoradiographic analysis of cell generation using tritiated thymidine. J Comp Neurol 188:263-272.

Cepko CL (1996) The patterning and onset of opsin expression in vertebrate retinae. Curr Opin Neurobiol 6:542-546.

Cepko CL, Austin CP, Yang X, Alexiades M, Ezzeddine D (1996) Cell fate determination in the vertebrate retina. Proc Natl Acad Sci USA 93:589-595.

Chen S, Wang Q-L, Nie A, Sun H, Lennon G, Copeland NG, Gilbert DJ, Jenkins NA, Zack DJ (1997) Crx, a novel otx-like pairedhomeodomain protein, binds to and transactivates photoreceptor cellspecific genes. Neuron 19:1017-1030.

Dorsky RI, Rapaport DH, Harris WA (1995) Xotch inhibits cell differentiation in the Xenopus retina. Neuron 14:487-496.

Ezzeddine ZD, Yang X, DeChiara T, Yancopoulos G, Cepko CL (1997) Postmitotic cells fated to become rod photoreceptors can be respecified by CNTF treatment of the retina. Development 124:1055-1067.

Fuhrmann S, Kirsch M, Hofmann H-D (1995) Ciliary neurotrophic factor promotes chick photoreceptor development in vitro. Development 121:2695-2706.

Furukawa T, Morrow EM, Cepko CL (1997) Crx, a novel otx-like homeobox gene shows photoreceptor-specific expression and regulates photoreceptor differentiation. Cell 91:531-541.

Hitchcock PF, Macdonald RE, VanDeRyt JT, Wilson SW (1996) Antibodies against Pax6 immunostain amacrine and ganglion cells and neuronal progenitors, but not rod precursors, in the normal and regenerating retina of the goldfish. J Neurobiol 29:399-413.

Hunter DD, Murphy MD, Olsson CV, Brunken WJ (1992) S-laminin expression in adult and developing retinae: a potential cue for photoreceptor morphogenesis. Neuron 8:399-413.

Kelley MW, Turner JK, Reh TA (1994) Retinoic acid promotes differentiation of photoreceptors in vitro. Development 120:2091-2102.

Kirsch M, Fuhrmann S, Wiese A, Hofmann H-D (1996) CNTF exerts opposite effects on in vitro development of rat and chick photoreceptors. NeuroReport 7:697-700.

Kumar R, Chen S, Scheurer D, Wang Q-L, Duh E, Sung CH, Rehemtulla A, Swaroop A, Adler R, Zack DJ (1996) The bZIP transcription factor $\mathrm{Nrl}$ stimulates rhodopsin promoter activity in primary retinal cell cultures. J Biol Chem 271:29612-29618.

Lillien L, Cepko C (1992) Control of proliferation in the retina: temporal changes in responsiveness to FGF and TGF alpha. Development $115: 253-266$.
Liou GI, Wang M, Matragoon S (1994) Timing of interphotoreceptor retinoid-binding protein (IRBP) gene expression and hypomethylation in developing mouse retina. Dev Biol 161:345-356.

Liu IS, Chen JD, Ploder L, Vidgen D, van der Kooy D, Kalnins VI, McInnes RR (1994) Developmental expression of a novel murine homeobox gene (Chx10): evidence for roles in determination of the neuroretina and inner nuclear layer. Neuron 13:377-393.

Molday RS (1989) Monoclonal antibodies to rhodopsin and other proteins of rod outer segments. Prog Ret Res 8:173-209.

Neophytou C, Vernallis AB, Smith A, Raff MC (1997) Muller-cellderived leukemia inhibitory factor arrests rod photoreceptor differentiation at a postmitotic pre-rod stage of development. Development 124:2345-2354

Reh TA (1991) Determination of cell fate during retinal histogenesis: intrinsic and extrinsic mechanisms. In: Development of the visual system (Lam DM-K, Shatz CJ, eds), pp 79-94. Cambridge: MIT.

Rehemtulla A, Warwar R, Kumar R, Ji X, Zack DJ, Swaroop A (1996) The basic motif-leucine zipper transcription factor $\mathrm{Nrl}$ can positively regulate rhodopsin gene expression. Proc Natl Acad Sci USA 93:191-195.

Rodriquez A, Dunhardt FT (1960) Preparation of a semi-permanent mounting medium for fluorescent studies. Virology 12:316-317.

Sidman RL (1970) Autoradiographic methods and principles for study of the nervous system with thymidine $\mathrm{H}^{3}$. In: Contemporary research in neuroanatomy (Nauta E, ed), pp 252. New York: Springer.

Tomita K, Ishibashi M, Nakahara K, Ang S-L, Nakanishi S, Guillemot F, Kageyama R (1996) Mammalian hairy and Enhancer of Split homolog 1 regulates differentiation of retinal neurons and is essential for eye morphogenesis. Neuron 16:723-734.

Treisman J, Morabito MA, Barnstable C (1988) Opsin expression in the rat retina is developmentally regulated by transcription activation. Mol Cell Biol 8:1570-1579.

Turner DL, Cepko CL (1987) A common progenitor for neurons and glia persists in rat retina late in development. Nature 328:131-136.

Voyvodic JT, Burne JF, Raff MC (1995) Quantification of normal cell death in the rat retina: implications for clone composition in cell lineage analysis. Eur J Neurosci 7:2469-2478.

Watanabe T, Raff MC (1990) Rod photoreceptor development in vitro: intrinsic properties of proliferation neuroepithelial cells change as development proceeds in the rat retina. Neuron 2:461-467.

Young RW (1984) Cell death during differentiation of the retina in the mouse. J Comp Neurol 229:362-373. 